\section{REPLY TO THE COMMENTS OF A READER ON "HERPETOFAUNA OF NALLAMALAI HILLS WITH ELEVEN NEW RECORDS FROM THE REGION INCLUDING TEN NEW RECORDS FOR ANDHRA PRADESH"}

\section{K. Thulsi Rao}

Ecological Research \& Monitoring Laboratories, Nallamalai Hill Ranges, Eastern Ghats, Project Tiger Circle, Srisailam, Kurnool District, Andhra Pradesh 518102, India

Email: thulsirao@yahoo.co.in

This is with reference to the comments made by a reader on Herpetofauna of Nallamalai Hills with eleven new records from the region including ten new records for Andhra Pradesh by Rao et al. (2005)" published in Zoos' Print Journal 20(1): 17371740. Following are the remarks given under each of the comments.

\section{The inclusion of Rollapadu Wildlife Sanctuary is} erroneous, and it has nothing to do with the geographically distinct Nallamalai Hills.

The introduction of our paper makes it clear that the present work refers to the three protected areas of the Nallamalai region. Nallamalai region includes the upland forest belt, and the lowland plains that encompasses the habitations, the croplands and other topographical features, as a part of the larger Nallamalai landscape. The whole area is a geographical, hydrological, climatoligical, pedological, ecological and anthropogenically homogeneous unit of intrinsically linked landscape, which needs an integrated approach for conservation of the natural resources.

As per the Biogeographic classification of India (Rodgers \& Panwar, 2002); all the three protected areas of Nallamalais, fall under same biotic province (06E: Deccan peninsula/ Deccan South) and zone IV d2 \& Vc. of eco-floristic zones of Andhra Pradesh (FAO, 1989). Further, Eastern Ghats is a composition of hills of southeastern India and associated plains (Das, 1996).

In this context the authors considered the Rollapadu Wildlife Sanctuary as one subset of the Nallamalai region.

2. The legend of the map of the study area (on page 1740) detailing the collection sites includes wrong depiction of the coordinates of each location. The coordinates provided are values of decimal latitude and longitude represented in minutes and degree format.

The legend of the map of the study area (on page 1740) detailing the collection sites, depicts the correct coordinates in decimal measurements only. The superscripts are added subsequently by the computer operator, before mailing the manuscript.

(C) Zoo Outreach Organisation; www.zoosprint.org Response to comments received 20 February 2005; Edited and accepted 12 March 2005; Date of publication 21 March 2005
Nevertheless, the correct names of the locations were also given in the paper, which undermines this typographical error. We are providing correct values in Table 1 in this reply.

3. The claim of the new records of Calotes rouxii (Duméril and Bibron, 1837) (Squamata: Agamidae) and Lycodon striatus (Shaw, 1802) (Squamata: Colubridae) is not correct as both these taxa have been recorded from Rollapadu Wildlife Sanctuary and its vicinity by Srinivasulu \& Srinivasulu (2004).

4. Other erroneous regional first record claims pertains to Bufo scaber (Schneider, 1799) (Amphibia: Bufonidae) and Geochelone elegans (Schoepff, 1795) (Testudines: Testudinidae) that was reported from the Nallamala Hills by Subba Rao et al. (1994).

The above claims cannot be accepted as these (faunistic records) are being reported in grey literature and in a self edited seminar proceedings and not verified by any standard procedure (for eg. by a referee) and are without any voucher specimens in hand.

The conference (congress, symposium, workshop, panel discussion, seminar, and colloquium), the proceedings reports are not considered as validly published as primary data (Day, 1996), because:

(i) Most conference proceedings are one-shot, ephemeral publications, not purchased widely by science libraries around the world; thus, because of limited circulation and availability, they fail one of the fundamental tests of valid publication.

(ii) Most conference reports are essentially review papers, which do not qualify as primary publications, or they are preliminary reports presenting data and concepts that may still be tentative or inconclusive. (It is sad to see scientists describing new species in conference abstract as we recently came across two such symposium abstracts in 2005 !. This is in clear contradiction of the rules. It is also surprising that Conveners are not taking necessary steps to prevent this).

(iii) Conference reports are normally not subjected to peer review or to more than minimal editing; therefore, because of lack of any real quality control, many reputable publishers now define proceedings volumes as non primary.

However, the authors invite the attention of the reader to the following: In fact the occurrence of Calotes rouxii (Duméril and Bibron, 1837) (Squamata: Agamidae) and Lycodon striatus (Shaw, 1802) (Squamata: Colubridae) was already reported by the first author in the Management Plans (Rao, 2000, 2002, 2003), duly approved by the competent authority.

5. Inclusion of Cerebrus rynchops (Squamata: Colubridae) based on sighting. This taxon is a saltwater and estuarine species and its presence on the Nallamala Hills is unquestionably a case of wrong identification.

There is an earlier study which states that the occurrence of 
Cerebrus rynchops in fresh water more than 100 miles (>160km) (Smith, 1943) away from the river mouth/brackish waters. There is every possibility that this species must have migrated upstream of the River Krishna which cuts across the Nallamalai region over $150 \mathrm{~km}$. However, we do not have the specimen at hand and our report is purely based on sighting. The reader cannot ignore certain happenings of nature which forces the species to adapt to new environments.

6. Kaloula taprobanica Parker, 1934 (Amphibia: Microhylidae) was recorded from Andhra Pradesh by Sivakumar et al. (2003) based on specimens collected at Sriharikota Island, Nellore district.

We agree with the reader and this should be shifted to the first record for the Nallamalai region. We thank the reader for bringing it to our knowledge.

7. Sphaeroteca rolandae (Dubois, 1983) (Amphibia: Ranidae) (listed as Tomopterna rolandae by Rao et al., 2005) is based on wrong identification of the specimen, which is that of Sphaeroteca breviceps (Schneider, 1799)

The readers comment on Tomopterna rolandae is invalid, as this specimen has rightly been identified by experts like Dr. Anand Padhye (Garware College, Pune) and Dr. S. Kamble (Scientist, ZSI, Pune). We do not know how the reader has come to conclusion without verifying the specimen. Sphaeroteca rolandae (Dubois, 1983) (Amphibia: Ranidae) listed as Tomopterna rolandae was identified on the basis of description given in S.K. Dutta (1997) and S.K. Chanda (2002). We agree we forgot to change Tomopterna to Sphaeroteca, as it is now accepted that there is no Tomopterna in India. Tomopterna rolandae has been confused with $T$. breviceps in most of the previous publications also by the experts, which is widely distributed in India (Dutta, 1997) and the two differ from each other only slightly. (The said specimen is being sent for additional comments to another expert. Since the voucher specimen is with us it will be possible to settle the issue and such practices are common in taxonomy). A fuller length paper giving diagnostic features and diagrams is intended to clarify the matters further.

Besides, nomenclature of Indian amphibian has undergone many changes of late and we feel some automated software must be introduced to change the wrong names to correct ones! Sphaerotheca or Sphaeroteca for example, which is correct? Sphaerotheca is also a genus in Fungi and list of amphibians of the world on the web still uses Sphaerotheca and it is the same spelling originally used by Alain Dubois.

8. The claim of occurrence of Polypedates leucomystax (Gravenhorst, 1829) is also erroneous as the species is restricted in distribution to northeast region from West Bengal and eastwards in India and the specimen collected from the Nallamala Hills is one of the adult male morphotype (Image $15^{w}$ on page iii of the web supplement) of Polypedates maculatus (Gray \& Hardwicke, 1834).
The identity of the specimen as Polypedates leucomystax (Gravenhorst, 1829) was confirmed by experts Dr. Anand Padhye (Garware College, Pune), Dr. S. Kamble (Scientist, ZSI, Pune) and even seen by others like Dr. C. Srinivasulu.

9. Despite providing the photograph (Image $42^{w}$ on page ix of the web supplement) the authors have missed including Ahaetulla nasuta (Lacépède, 1789) - a very common rearfanged snake in the Nallamala Hills. Instead they have included a subspecies nomen assigned for a specimen collected from Mallelateertham, which warrants detailed pholidosis studies to establish its identity. I have seen this specimen in the ERM lab and feel that it shows characters intermediate between Ahaetulla nasuta (Lacépède, 1789) and Ahaetulla pulverulenta (Duméril, Bibron \& Duméril, 1854).

The first manuscript sent by us included both the specimens as two different species. In response to comments from the reviewers' made on the first version of our MS (No. 1232) we agreed to accept both as one species but for the colour morph. In this connection we draw the attention of the reader that both Ahaetulla nasuta and Ahaetulla nasutus isabellinus are same species nothing more than a colour morph within the species (Smith, 1943). The specimen was again confirmed by two expert taxonomists on Indian snakes (A. Captain \& V. Giri).

10. The record of Mabuya beddomii (Jerdon, 1870) is based on wrong identification of the voucher, which is that of the Andhra Pradesh endemic Mabuya nagarjuni Sharma, 1969 (Image $30^{w}$ on page vii of the web supplement shows Mabuya nagarjuni Sharma, 1969).

The claim of the reader is invalid, as the specimen Mabuya beddomii (Jerdon, 1870) was rightly identified on the basis of description given in page no. $274-275$ (Smith, 1935). Though we know the occurrence of the other species, we could not incorporate that in the list, as we have not sighted Mabuya nagarjuni (Sharma, 1969) during our study.

11. Rao et al. (2005) include Sibynophis subpunctatus (with wrong common name of Cantor's Black-headed Snake instead of Dumeril's Black-headed Snake) in the catalogue and go to claim it as first record from Andhra Pradesh. Earlier, Rao \& Sekar (1993) had reported the Cantor's Blackheaded Snake Sibynophis saggitaria (Cantor, 1839) from Sriharikota Island, Nellore district. With recent resurrection of the nomen subpunctatus from the synonymy of Sibynophis saggitaria (Cantor, 1839) by Captain et al. (2004), all records pertaining to that of the latter nomen would be assigned to the resurrected nomen, thus invalidating Rao et al.'s (2005) claim

We disagree with the readers view. We referred the note published by Rao and Sekar (1993) in which they mentioned that the specimen collected by them was Sibynophis saggitaria. They also gave a reference of occurrence of Dumeril's Blackheaded Snake in Tamil Nadu. We also bring it to the notice of the reader that the first record of the S. saggitaria was also claimed by Sanyal et al. (1993) from East Godavari. 
Table 1. Corrected coordinates of collection sites provided by Rao et al. (2005) [The coordinates provided by Rao et al. (2005) are given in parenthesis under site names]

\begin{tabular}{|c|c|c|c|c|c|}
\hline & \multirow[t]{2}{*}{ Collection site } & \multicolumn{2}{|c|}{ Decimal } & \multicolumn{2}{|c|}{ Degrees / Minutes } \\
\hline & & Latitude & Longitude & Latitude & Longitude \\
\hline 1. & $\begin{array}{l}\text { Vijayapuri } \\
\left(16^{\circ} 58^{\prime} \text { N \& } 79^{\circ} 32^{\prime} \mathrm{E}\right)\end{array}$ & 16.58 & 79.32 & $16^{\circ} 34^{\prime}$ & $79^{\circ} 19^{\prime}$ \\
\hline 2. & $\begin{array}{l}\text { Mannanur } \\
\left(16^{\circ} 58^{\prime} \text { N \& } 78^{\circ} 74^{\prime} \mathrm{E}\right)\end{array}$ & 16.58 & 78.74 & $16^{\circ} 34^{\prime}$ & $78^{\circ} 44^{\prime}$ \\
\hline 3. & $\begin{array}{l}\text { Mallelateertham } \\
\left(16^{\circ} 24^{\prime} \mathrm{N} \& 78^{\circ} 82^{\prime} \mathrm{E}\right)\end{array}$ & 16.24 & 78.82 & $16^{\circ} 14^{\prime}$ & $78^{\circ} 49^{\prime}$ \\
\hline 4. & $\begin{array}{l}\text { Appapur } \\
\left(16^{\circ} 18^{\prime} \text { N \& } 78^{\circ} 67^{\prime} \mathrm{E}\right)\end{array}$ & 16.18 & 78.67 & $16^{\circ} 10^{\prime}$ & $78^{\circ} 40^{\prime}$ \\
\hline 5. & $\begin{array}{l}\text { Saileswarama/Rampur Penta } \\
\left(16^{\circ} 18^{\prime} \mathrm{N} \& 78^{\circ} 65^{\prime} \mathrm{E}\right)\end{array}$ & 16.18 & 78.65 & $16^{\circ} 10^{\prime}$ & $78^{\circ} 39^{\prime}$ \\
\hline 6. & $\begin{array}{l}\text { Sunnipenta/Shikaram } \\
\left(16^{\circ} 07^{\prime} N \text { \& } 78^{\circ} 91^{\prime} E\right)\end{array}$ & 16.07 & 78.91 & $16^{\circ} 04^{\prime}$ & $78^{\circ} 54^{\prime}$ \\
\hline 7. & $\begin{array}{l}\text { Chinnarutla } \\
\left(16^{\circ} 04^{\prime} N \text { \& } \& 8^{\circ} 95^{\prime} E\right)\end{array}$ & 16.04 & 78.95 & $16^{\circ} 02^{\prime}$ & $78^{\circ} 39^{\prime}$ \\
\hline 8. & $\begin{array}{l}\text { Pulicheruvu } \\
\text { (15॰99' N \& 78०92' E) }\end{array}$ & 15.99 & 78.92 & $15^{\circ} 59^{\prime}$ & $78^{\circ} 55^{\prime}$ \\
\hline 9. & $\begin{array}{l}\text { Thummalabailu } \\
\left(15^{\circ} 96^{\prime} N \text { \& } 78^{\circ} 93^{\prime} E\right)\end{array}$ & 15.96 & 78.93 & $15^{\circ} 57^{\prime}$ & $78^{\circ} 55^{\prime}$ \\
\hline 10. & $\begin{array}{l}\text { Peddacheruvu } \\
\left(15^{\circ} 95^{\prime} \text { N \& } 78^{\circ} 84^{\prime} \text { E) }\right.\end{array}$ & 15.95 & 78.84 & $15^{\circ} 34^{\prime}$ & $78^{\circ} 30^{\prime}$ \\
\hline 11. & $\begin{array}{l}\text { Pedda Dornal } \\
\left(15^{\circ} 93^{\prime} \text { N \& } 78^{\circ} 09^{\prime} \text { E) }\right.\end{array}$ & 15.93 & 78.09 & $15^{\circ} 55^{\prime}$ & $79^{\circ} 05^{\prime}$ \\
\hline 12. & 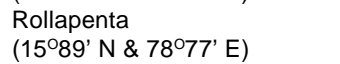 & 15.89 & 78.77 & $15^{\circ} 53^{\prime}$ & $78^{\circ} 46^{\prime}$ \\
\hline 13. & $\begin{array}{l}\text { Rollapadu WL Sanctuary } \\
\left(15^{\circ} 75^{\prime} N \text { N \& } 78^{\circ} 36^{\prime} \text { E) }\right.\end{array}$ & 15.75 & 78.36 & $15^{\circ} 45^{\prime}$ & $78^{\circ} 21^{\prime}$ \\
\hline 14. & $\begin{array}{l}\text { Pangidi Vagu } \\
\left(15^{\circ} 76^{\prime} \text { N \& } 78^{\circ} 70^{\prime} \text { E) }\right.\end{array}$ & 15.76 & 78.70 & $15^{\circ} 45^{\prime}$ & $78^{\circ} 42^{\prime}$ \\
\hline 15. & $\begin{array}{l}\text { GBM Temple/Guest House } \\
\left(15^{\circ} 66^{\prime} \mathrm{N} \& 78^{\circ} 74^{\prime} \mathrm{E}\right)\end{array}$ & 15.66 & 78.74 & $15^{\circ} 39^{\prime}$ & $78^{\circ} 44^{\prime}$ \\
\hline 16. & $\begin{array}{l}\text { Isukagundam } \\
\left(15^{\circ} 60^{\prime} \mathrm{N} \& 78^{\circ} 81^{\prime} \mathrm{E}\right)\end{array}$ & 15.60 & 78.81 & $15^{\circ} 36^{\prime}$ & $78^{\circ} 48^{\prime}$ \\
\hline
\end{tabular}

Our paper was sent for publication before the resurrection of the nomen subpunctatus from the synonymy of Sibynophis saggitaria (Cantor, 1839) by Captain et al. (2004).

The first author of the paper by Rao et al. (2005) is a qualified researcher, scientist and a professional protected area manager, with over 30 years of experience both in in situ and ex situ conservation dedicatedly working for the cause of conservation of biodiversity in the Eastern Ghats, while the second author is a reputed scientist duly recognized in wildlife biology both within and outside the country.

\section{REFERENCES}

Captain, A., D.J. Gower, P. David and A.M. Bauer (2004). Taxonomic status of the colubrid snake Sibynophis subpunctatus (Duméril, Bibron \& Duméril, 1854). Hamadryad 28(1\&2): 90-94.

Chanda, S.K. (2002). Handbook - Indian Amphibians. Zoological Survey of India, Calcutta, viii+335pp.

Das, I. (1996). Biogeography of the Reptiles of South Asia. Published by Krieger Publishing Company, Krieger Drive, Florida, 86 pp.

Day, R.A. (1996). How to write and publish a scientific paper, $4^{\text {th }}$ edition. Cambridge University Press, 223 pp.

Dutta, S.K. (1997). Amphibia of India and Sri Lanka (Checklist and Bibliography). Odyssey Publishing House, Bhubaneswar, Orissa, xxii+342pp.

FAO (1989). A Report on eco-floristic zones map of Tropical Asia Rao, P. and A.G. Sekar (1993). Occurrence of Cantor's Blackheaded Snake Sibynophis sagittarius in Sriharikota, Andhra Pradesh. Journal of the Bombay Natural History Society 90(1): 114.

Rao, K.T. (2000). Management Plan of Nagarjunasagar Srisailam Tiger
Reserve. A.P. Forest Department.

Rao, K.T. (2002). Management Plan of Rollapadu Wildlife Sanctuary. A.P. Forest Department.

Rao, K.T. (2003). Management Plan of Gundlabrahmeswaram Wildlife Sanctuary. A.P. Forest Department.

Rao, K.T., H.V. Ghate, M. Sudhakar, S.M. Maqsood Javed and I. Siva Rama Krishna (2005). Herpetofauna of the Nallamalai Hills with eleven new records from the region including ten new records for Andhra Pradesh. Zoos' Print Journal 20(1): 1737-1740 + web supplement.Rodgers, W.A., H.S. Panwar and V.B. Mathur (2002). Wildlife Protected Area Network in India: A Review. Wildlife Institute of India, Dehradun.

Sanyal, D.P., B.D. Gupta and N.C. Gayen (1993). Reptilia, State Fauna Series 5, Fauna of Andhra Pradesh, Part - I: 1-63, Zoological Survey of India, Calcutta.

Smith, M.A. (1935). The Fauna of British India including Ceylon and Burma. Reptila and Amphibia, Volume II Sauria. Today and Tomorrow's Printers \& Publishers, New Delhi (Indian Reprint, 1981), 440pp.

Smith, M.A. (1943). The Fauna of British India including Ceylon and Burma. Reptila and Amphibia, Volume III Serpentes. Today and Tomorrow's Printers \& Publishers, New Delhi (Indian Reprint, 1981), $583 \mathrm{pp}$. 